\title{
PERCEPTIONS OF DRUGS BENEFITS AND BARRIERS TO QUIT BY UNDERGRADUATE HEALTH STUDENTS
}

Patricia Cid Henriquéz ${ }^{1}$

Ana Maria Pimenta de Carvalho ${ }^{2}$

Cid Henríquez P, Carvalho AMP. Perceptions of drugs benefits and barriers to quit by undergraduate health students. Rev Latino-am Enfermagem 2008 maio-junho; 16(especial):621-6.

Several studies have exposed the consumption of drugs by undergraduate students in the health area, who are supposed to be examples of behavior and health educators. This descriptive correlation study aimed to relate the benefits of tobacco consumption and barriers to quit according to the perception of undergraduate students. Eighty third-year students, in three different courses, answered a self-applied questionnaire. The studied variables were: consumption conditions, barriers and benefits regarding drug consumption, family and personal characteristics. One-third of the students reported tobacco use; $5 \%$ reported the use of marijuana; $15 \%$ alcohol and 6\% tranquilizers, more than once a month; $18 \%$ reported the consumption of tobacco and $13 \%$ reported the use of alcohol even before the age of 15 . The perceived benefits were: relaxation, pleasure and social acceptance, whereas barriers for quitting were: habituation and addiction. According to the results, promoting self-responsibility of these future health professionals is recommended in their educational context.

DESCRIPTORS: students; substance related disorders; health; nursing

\section{PERCEPCIÓN DE LOS BENEFICIOS DEL CONSUMO DE DROGAS Y BARRERAS PARA SU ABANDONO ENTRE ESTUDIANTES DEL ÁREA DE SALUD}

Diversos estudios evidencian consumo de drogas en estudiantes universitarios del área de la salud, de quienes se espera que sean modelos de rol y educadores en salud. El propósito de esta investigación descriptivacorrelacional fue establecer los beneficios que perciben los estudiantes universitarios del área de la salud para consumir tabaco y las barreras para abandonarlo. Respondieron un cuestionario autoadministrado 80 estudiantes del tercer año de tres carreras de salud. Las variables fueron condición de consumo, barreras y beneficios percibidos del consumo de drogas y características personales y familiares. Un tercio de los estudiantes fumaba tabaco. Más de una vez al mes declararon consumir marihuana un 5\%; alcohol 15\%; tranquilizantes 6\%. Antes de los 15 años ya fumaba un 18\% y un 13\% bebía. Beneficios percibidos del consumo son relajación, placer y aceptación social, y barreras percibidas para el abandono son habituación y adicción. Se recomienda motivar a los futuros profesionales a la autoresponsabilidad con su salud.

DESCRIPTORES: estudiantes; transtornos relacionados con sustancias; salud; enfermería

\section{PERCEPCÃO DOS BENEFÍCIOS DO CONSUMO DE DROGAS E DAS BARREIRAS PARA SEU ABANDONO ENTRE ESTUDANTES DA ÁREA DA SAÚDE}

Diversos estudos evidenciam o consumo de drogas entre estudantes universitários da área da saúde, de quem se espera comportamentos modelo em relação ao cuidado com a saúde. O objetivo deste estudo foi acessar a percepção de estudantes universitários de três carreiras diferentes na área da saúde, quanto às barreiras para deixar de consumir e os benefícios do consumo. Responderam a um questionário autoadministrável 80 estudantes do terceiro ano. As variáveis estudadas foram: condição de consumo, barreira e benefícios relacionados ao consumo ou deixar de consumir drogas, características pessoais e familiares. Um terço dos estudantes relatou uso de tabaco; 5\% relataram usar maconha mais de uma vez ao mês; $15 \%$ relataram consumo de álcool e $6 \%$ de tranqüilizantes; $18 \%$ relataram serem fumantes, e $13 \%$ reportaram consumo de álcool desde antes dos 15 anos. Os benefícios do consumo são: relaxamento, sentimento de prazer, aceitação social. As barreiras para deixar de consumir referem-se à habituação e vício. Recomenda-se criar, no contexto da formação desses profissionais, auto-responsabilidade no cuidado com a saúde.

DESCRITORES: estudantes; transtornos relacionados ao uso de substâncias; saúde; enfermagem

${ }^{1}$ RN, M.Sc. in Nursing, University of Concepción, Chile; ${ }^{2}$ Psychologist, Faculty, University of São Paulo at Ribeirão Preto, College of Nursing, WHO Collaborating Centre for Nursing Research Development, Brazil, e-mail: anacar@eerp.usp.br 


\section{INTRODUCTION}

This century has been marked by the importance healthcare has gained in social policies that favor the population's biopsychosocial welfare. Healthcare could not be provided for everyone in 2000, but the focus has been changed from disease to health.

Health is a human right that is closely related to life and, as human rights are related to human care, healthcare involves not only actions that benefit people's health, but also one's own health ${ }^{(1-2)}$. All people have to limit their freedom, both for their own benefit and for the benefit of others, by not performing actions that harm their health, such as the consumption of illicit drugs, tobacco or alcohol.

The consumption of alcohol, tobacco and other drugs acknowledgedly has a negative influence on people's health, thus constituting a Public Health problem. Global tendencies reflect an increase in the use of licit and illicit drugs, especially by young people, since drugs use has started at earlier ages ${ }^{(3)}$.

The term drug is defined as "any psychoactive substance, including alcohol, tobacco, inhalants and drugs, which are self-administered without any medical supervision and aimed at changing someone's mood, behavior or thought, or simply for the purpose of having fun"(4).

Studies about drugs among the general population of Chile in 1994 showed that the licit drug most often consumed was alcohol, followed by tobacco. They also made it evident that one out of eight Chilean people, from 12 to 64 years old, had already consumed at least one of the three illegal drugs studied (marijuana, coca paste or cocaine) at least once in their lives ${ }^{(5)}$. Over the years, the prevalence of tobacco consumption has increased from $38.94 \%$ in 1994 to $42.54 \%$ in 2004 , due to a greater proportion of women who smoke ${ }^{(6)}$. The young population, from 19 to 25 years old, presents the highest consumption prevalence, in which men showed a slight variation (59.33 to 59.73) over these 10 years, whereas young women increased tobacco consumption prevalence by over 10 points ( 42.54 to 55.01$)^{(6)}$.

As the consumption of tobacco increased, the number of deaths caused by tobacco consumption unfortunately increased as well. In 1985, 11,872 people died, rising to 15,088 people in 2005. In other words, the number of deaths caused by tobacco consumption increased by 4,000 in 20 years, until $2005^{(7)}$.

Tobacco is a licit drug, considered harmful to people's health. This damage is caused by approximately 4,000 chemical components its smoke contains, namely nicotine (a chemical substance that causes addiction), tar (associated to the development of some kinds of cancer) and carbon monoxide (a toxic gas that delays or blocks the transportation of oxygen in the bloodstream) ${ }^{(8)}$.

Studies have exposed a high prevalence of tobacco consumption among healthcare professionals, and this consumption is found to be higher among young professionals. Other relevant findings show that the prevalence of consumption in healthcare professionals is higher than the levels found in studies about the general population ${ }^{(9-10)}$. The latter constitutes an alarming fact, since these people are in a unique position to promote strategies to prevent and quit the consumption of drugs. Besides, they are aware of the risk factors this consumption causes to their health and to the health of their future patients ${ }^{(11)}$.

Undergraduate students from the health area, who are supposed to be an example of behavior and health educators, are not exempt from this habit either. A study has observed that students who smoked did not agree that they should be examples of good behavior ${ }^{(12)}$. Other descriptive studies have found that these students showed a lower prevalence of consumption than health professionals and the population in general, and they consumed less tobacco than undergraduate students from other areas not related to healthcare ${ }^{(13-14)}$.

Students from the health area prepare themselves to take care of people, but how do they take care of themselves? Those students, who are already taking the third year of a healthcare course, are expected to recognize that drugs damage people's health and to avoid its consumption. It is contradictory to think that the consumption of drugs is harmful for other people but not for their own health.

In this context, it is important to know the attitudes and/or motives of undergraduate students from different careers in the health area, who will work with disease prevention and health promotion.

The purpose of this study was to identify whether undergraduate students from the health area perceive benefits in the consumption of tobacco and other drugs, as well as the barriers to quit the consumption of these substances.

\section{METHODOLOGY}

This descriptive and correlational study was carried out with the participation of 80 undergraduate students, in the second semester of 2005 and the 
first semester of 2006. The study universe consisted of 400 students, who were in the third year of three different courses in the healthcare area, at a university in Concepción, Chile. The course level was selected at random, and the non-probabilistic sample was composed by students who agreed to participate in the study.

A self-applied questionnaire was elaborated for this study and used for data collection. This instrument included biodemographical questions, a scale of risk factors and questions related to the study variables. Students answered this questionnaire at university, during class, after approving and signing the informed consent term.

Prior to data collection, an experimental test was applied, in order to make sure students understood the instrument and observe the time needed for its application. Ten undergraduate nursing students, from the first year of the course, agreed and participated in this stage. They took around 15 minutes to answer the test and did not show any difficulties regarding the focus of the questions.

Data were analyzed through descriptive (frequencies, percentages) and inferential (correlation) statistics. These data were then processed through SPSS version 12.0 software, at the Nursing Department of the University of Concepción.

After approval by the Ethics Committee at the School of, the administrators of the health courses were informed about the study and its purposes.

\section{RESULTS}

The study sample presented the characteristics shown in Table 1.

Table 1 - Student characteristics. Concepción, 2006

\begin{tabular}{lccc}
\hline & Frequency & Percentage & $\begin{array}{c}\text { Accumulated } \\
\text { Percentage }\end{array}$ \\
\hline Age & & 52.5 & 52.5 \\
20 to 21 years old & 42 & 40.0 & 92.5 \\
22 to 23 years old & 32 & 6.25 & 98.75 \\
24 to 25 years old & 5 & 1.25 & 100.0 \\
26 to 27 years old & 1 & 100 & \\
Total & 80 & & 56.9 \\
Gender & & 56.9 & 100.0 \\
Female & 61 & 43.1 & \\
Male & 19 & 100.0 & \\
Total & 80 & & 39.0 \\
Course & & 39.0 & 71.0 \\
Nursing & 31 & 32.0 & 100.0 \\
Medicine & 26 & 29.0 & \\
Obstetrics & 23 & 100.0 & \\
Total & 80 & &
\end{tabular}

Students' ages varied from 20 to 27 years old, with more than half of them being female. Over one-third studied Nursing, and nearly one-third were taking Medicine. A smaller proportion studied Obstetrics.

The sample distribution according to the consumption of drugs is presented in Table 2 .

Table 2 - Distribution of undergraduate students from three different courses in the health area, according to the consumption of drugs. Concepción, 2006

\begin{tabular}{|c|c|c|c|}
\hline & Frequency & Percentage & $\begin{array}{c}\text { Accumulated } \\
\text { Percentage }\end{array}$ \\
\hline \multicolumn{4}{|l|}{$\begin{array}{l}\text { Monthly consumption of } \\
\text { drugs }\end{array}$} \\
\hline No consumption & 45 & 56.3 & 56.3 \\
\hline One kind of drugs & 22 & 27.8 & 83.8 \\
\hline Two kinds of drugs & 11 & 13.8 & 13.8 \\
\hline Three kinds of drugs & 2 & 2.4 & 97.6 \\
\hline Total & 80 & 100.0 & \\
\hline \multicolumn{4}{|l|}{$\begin{array}{l}\text { How long have they } \\
\text { been smoking? }\end{array}$} \\
\hline Does not smoke & 49 & 61.3 & 61.3 \\
\hline 1 to 3 years & 11 & 13.8 & 75.1 \\
\hline 4 to 6 years & 13 & 16.3 & 91.4 \\
\hline 7 to 9 years & 5 & 6.3 & 97.7 \\
\hline Over 10 years & 2 & 2.3 & 100.0 \\
\hline Total & 80 & 100.0 & \\
\hline \multicolumn{4}{|l|}{$\begin{array}{l}\text { When did they start } \\
\text { smoking? }\end{array}$} \\
\hline Does not smoke & 44 & 55.0 & 55.0 \\
\hline 11 to 12 years old & 5 & 6.3 & 61.3 \\
\hline 13 to 14 years old & 5 & 6.3 & 67.6 \\
\hline 15 to 16 years old & 9 & 11.2 & 78.8 \\
\hline 17 to 18 years old & 9 & 11.2 & 90.0 \\
\hline 19 to 20 years old & 5 & 6.3 & 96.3 \\
\hline 21 to 22 years old & 3 & 3.7 & 100.0 \\
\hline Total & 80 & 100 & \\
\hline
\end{tabular}

More than half of the students stated they did not consume any drugs monthly; less than onethird consumed some kind of drugs monthly; and $2.4 \%$ consumed three kinds of drugs a month. Within the total sample, two-thirds stated that they did not currently smoke, $16.3 \%$ had been smoking for four to six years; and $2.3 \%$ had been smoking for over 10 years. Regarding the age they started smoking, $12.6 \%$ of the students were between 11 and 14 years old at the time they started; $22.4 \%$ were from 15 to 18 , and $6.3 \%$ from 17 to 18 years old.

Table 3 presents the results regarding the use of tobacco and alcohol by relatives and friends, as well as the information provided by the academic disciplines about drugs. 
Table 3 - Distribution of undergraduate students from three different health courses, according to family characteristics and social environment, regarding the consumption of drugs. Concepción, 2006

\begin{tabular}{|c|c|c|c|}
\hline & Frequency & Percentage & $\begin{array}{l}\text { Accumulated } \\
\text { Percentage }\end{array}$ \\
\hline \multicolumn{4}{|l|}{ Relatives who smoke } \\
\hline None & 56 & 70.0 & 70.0 \\
\hline Less than half & 12 & 15.0 & 85.0 \\
\hline More than half & 11 & 14.0 & 99.0 \\
\hline Total & 79 & & \\
\hline Did not answer & 1 & & \\
\hline \multicolumn{4}{|l|}{ Relatives who drink } \\
\hline None & 52 & 65.0 & 65.0 \\
\hline Less than half & 10 & 12.5 & 77.5 \\
\hline More than half & 18 & 22.5 & 100 \\
\hline Total & 80 & & \\
\hline \multicolumn{4}{|l|}{ Friends who smoke } \\
\hline None & 22 & 27.0 & 27.0 \\
\hline Less than half & 26 & 32.0 & 59.0 \\
\hline More than half & 31 & 38.0 & 99.0 \\
\hline Total & 79 & 99.0 & \\
\hline Did not answer & 1 & & \\
\hline \multicolumn{4}{|l|}{$\begin{array}{l}\text { Disciplines provide } \\
\text { content about drugs? }\end{array}$} \\
\hline Yes & 32 & 40.0 & 40.0 \\
\hline No & 24 & 30.0 & 70.0 \\
\hline Did not remember & 24 & 30.0 & 100 \\
\hline Total & & 100 & \\
\hline
\end{tabular}

Most students state that they do not have relatives who smoke, whereas $15 \%$ of them do. However, according to these students, less than half of their relatives smoke. Almost two-thirds of the subjects mentioned that their relatives do not drink, and less than-one third said that more than half of their relatives drink. Regarding their friends' habits, $38 \%$ of the undergraduate students stated that more than half of their friends smoke, and nearly onethird said that less than half of them do so. $27 \%$ do not have friends who smoke. More than onethird of the students remembered that they received information on drugs in subjects taken in the previous semester; the others indicated that they did not have any information about it, or that they simply did not remember. Most of the students believed tobacco consumption is a problem, and it is important to pay closer attention to students who do not think so. They also present similar ideas about alcoholism; most of them say it is a problem, whereas few students say it is not.

Table 4 presents results regarding the kind of drug consumed more than once a month.
Table 4 - Distribution of undergraduate students according to the kind of drug consumed more than once a month, Concepción 2006

\begin{tabular}{lccc}
\hline \multicolumn{1}{c}{ Drugs } & Frequency & Percentage & $\begin{array}{c}\text { Accumulated } \\
\text { Percentage }\end{array}$ \\
\hline $\begin{array}{l}\text { Alcohol } \\
\text { Yes }\end{array}$ & 12 & 15.0 & 15.0 \\
$\quad$ No & 68 & 85.0 & 100 \\
Marijuana & & & \\
$\quad$ Yes & 4 & 5.0 & 5.0 \\
$\quad$ No & 76 & 95.0 & 100 \\
Tranquilizers & & & \\
Yes & 5 & 6.3 & 6.3 \\
No & 75 & 93.7 & 100 \\
Cocaine, heroine, & & & \\
LSD & & & \\
Yes & 1 & 1.3 & 1.3 \\
No & 79 & 98.7 & 100 \\
Inhalants & & & \\
Yes & 1 & 1.3 & 1.3 \\
No & 79 & 98.7 & 100 \\
\hline
\end{tabular}

More than two-thirds of the sample answered that they do not drink more than once a month, while $15 \%$ said the opposite. Four students consumed marijuana more than once a month, different from most participants, who did not use this substance. Nearly all students used neither cocaine, nor heroine or LSD.

Table 5 shows that over two-thirds of the students stated that they either do not use tobacco or have quit smoking. On the other hand, one-fifth considered themselves occasional smokers (consumption of less than seven cigarettes a week) and $11.3 \%$ were daily smokers (consumption of more than seven cigarettes a week).

Table 5 - Distribution of undergraduate students according to tobacco consumption. Concepción, 2006

\begin{tabular}{lccc}
\hline Consumption Condition & Frequency & Percentage & $\begin{array}{c}\text { Accumulated } \\
\text { Percentage }\end{array}$ \\
\hline $\begin{array}{l}\text { Non-smokers (or people } \\
\text { who have simply tried it) }\end{array}$ & 49 & 61.3 & 61.3 \\
$\begin{array}{l}\text { Ex-smokers (did not smoke } \\
\text { in the past year) }\end{array}$ & 6 & 7.5 & 68.8 \\
$\begin{array}{l}\text { Occasional smokers } \\
\text { (people who smoke less } \\
\text { than } 7 \text { cigarettes a week) }\end{array}$ & 16 & 20.0 & 88.8 \\
$\begin{array}{l}\text { Daily smokers (people who } \\
\text { smoke more than 7 } \\
\text { cigarettes a week) }\end{array}$ & 9 & 11.3 & 100.0 \\
\begin{tabular}{l} 
Total \\
\hline
\end{tabular} & 80 & 100.0 & 100.0 \\
\hline
\end{tabular}

Regarding their non-smoking behavior, onethird of the students answered it was a personal option, whereas students who smoke explained their smoking behavior by saying they had been influenced by friends. 
Most of the students perceived the following benefits of drugs consumption: relaxation, pleasure and social acceptance by peers. Barriers perceived for quitting drug consumption were habituation and its effects.

A negative correlation was observed between the condition of being a smoker and the study variables, such as the age students started smoking, how long they have been smoking, the number of cigarettes smoked per week, support for quitting alcohol, support for quitting tobacco and risk factors.

\section{DISCUSSION}

Some of the students who started the consumption of cigarettes early have maintained this consumption over the years, and have also started using other drugs. A relevant fact was the increase in consumption observed during the 15-to-18-year-old period since, during the last two years of this period (17 and 18 years old), they started going to university. Furthermore, a group of researchers has observed that students start smoking in their first year at the university, and those who already smoked before going to university increased their consumption frequency $^{(13)}$.

Ten students from this study started smoking before they were 14 years old, a fact that is similar to results found by studies with the Chilean national population $^{(15)}$.

More than two-thirds of the students stated that they do not consume any drugs, or have simply tried them; but the other third must be observed, especially because, as they advance in their studies, they start consuming other drugs ${ }^{(16)}$. Students who do not consume drugs said it was their personal option, showing a behavior that can be considered an intrinsic motivation, if compared to the results of other researchers ${ }^{(17)}$.

Undergraduate students in the healthcare area do perceive benefits in the consumption of tobacco. Examples are instance, relaxation, pleasure and social acceptance by their peers, and similar results have been observed in students from a healthcare university in Colombia ${ }^{(18)}$. Some researchers express that current lifestyles lead to this "consumer happiness" behavior, which aims for individual pleasure and leads to the "consumption of not only goods, but also one's own life"(19). The barriers identified were habituation and its effects.
Most of the students consider the consumption of alcohol and tobacco as a health problem, but it is alarming that some students from the healthcare area think that it is not, similarly to other studies with healthcare students and professionals who did not perceive any risks for themselves either - only for other people $\mathrm{e}^{(16,20)}$. Professionals and students from this area cannot deceive themselves by thinking that drugs are harmful for other people but not for them. The question is: how is it possible to show them that they are wrong?

Professionals who dedicate themselves to healthcare should facilitate a favorable environment to quit smoking, which should not inspire guilt or reproach in the person. Public health intervention initiatives should focus on equality models, the image and advantages of a drug-free lifestyle, instead of focusing only on the long-term consequences drugs represent to health.

People are free to make decisions in their lives, but this freedom is limited by social policies (for instance, the restriction on smoking in healthcare environments). As people choose a university career, they accept the behavior rules proposed by health organizations, such as the ethics codes, but do these codes really rule people's behavior?

By taking part in a university community, people develop their knowledge, such as the knowledge to know and do things, which loses strength when it is not followed by the knowledge to live and be. The authors recommend the establishment of strategies to develop the theme of drugs prevention and rehabilitation in the disciplines of careers that affect students' behavior. Furthermore, it is important to motivate future health professionals to keep up preventive behaviors and promote their selfresponsibility. In the disciplines of ethics, it is important to stress the social responsibility of health professionals and the value of human rights, such as health and life.

\section{ACKNOWLEDGEMENTS}

Acknowledgements to the Inter-American Drug Abuse Control Commission/CICAD of the SubSecretary of Multidimensional Security at the Organization of American States/OAS, the Brazilian Anti-Drugs Secretary/SENAD, faculty members at the University of São Paulo at Ribeirão Preto College of Nursing, WHO Collaborating Centre for Nursing 
Research Development, Brazil, to the population who participated in the studies and to the representatives from eight Latin-American countries who participated in the I and II On-Line Specialization Program for
Research Capacity-Building on the Drugs Phenomenon-PREINVEST, offered in 2005/2006 by the University of São Paulo at Ribeirão Preto College of Nursing, as a distance education course.

\section{REFERENCES}

1. Gómez-Lobo A. Principios complementarios de la racionalidad práctica: Los bienes humanos básicos. In: Los bienes humanos. Ética de la ley natural. Santiago: Editorial Mediterráneo; 2006. p. 25-45.

2. Gómez-Lobo A. La obtención de los bienes humanos: estrategias prudenciales. In: Los bienes humanos. Ética de la ley natural. Santiago: Editorial Mediterráneo; 2006. p. 63-9. 3. Pan American Journal of Public Health. Informe de Salud; 2002

4. Oficina de las Naciones Unidas contra las Drogas y el Delito (UNODC).

5. Ministerio de salud. Estudio Nacional de Drogas en Población General de Chile; 1994.

6. Ministerio de salud. Estudios Nacionales de Drogas en Población General de Chile 1994 - 2004.

7. Ministerio de salud. Departamento de estadísticas e información en salud. Mortalidad por 10 primeras causas en Chile. Disponible en http://deis.minsal.cl/ev/mortalidad_general/causas/as.asp

8. Müller F, Wehbe L (2006). Tabaquismo. ¿Qué es fumar? (segunda parte). Revista del CONAREC; 22(85):122-8.

9. Bello S, Soto M, Michalland S. Encuesta nacional de tabaquismo en funcionarios de salud. Rev Méd Chile 2004; 132:223-32.

10. Varona $P$, Fernández $N$, Bonet $M$, Garcia $R$, Ibarra $A$, Chang M. Tabaquismo y sus características en trabajadores de la salud. Rev Cubana Méd Gen Integr 2000; 16:221-26. 11. Puschel K, Thompson B, Coronado G, Rivera S, Daniel D, González L, Valencia G, Iñiguez S, Montero J. Tabaquismo en Atención Primaria: Perfil de fumadoras consultantes, creencias y actitudes de los equipos de salud y oportunidades de intervención. Rev Med Chile 2006; 134(6):726-34.

12. Milei J, Gomez E, Malateste JC, Grana DR, Cardozo O, Lizarraga AA. El Tabaquismo en Estudiantes de Medicina. Rev Fed Arg Cardiol 2000; 29:495-99.

13. Tafur LA, Ordóñez G, Millán JC, Varela JM, Rebellón P. Prevalencia de tabaquismo en estudiantes recién ingresados a la Universidad Santiago de Cali. Rev Colombia Méd 2006; $37(2): 126-32$.
14. Mas A, Nerín I, Barrueco M, Cordero J, Guillén D, JiménezRuiz C, Sobradillo V. Consumo de tabaco en estudiantes de sexto curso de medicina de España. Arch Bronconeumol $2004 ; 40(9): 403-8$.

15. Nerín I, Guillén $D$, Mas A, Crucelaegui A. Evaluación de la influencia que ejerce la facultad de medicina en los futuros médicos respecto al tabaquismo. Arch Bronconeumol 2004; 40:341-7.

16. Osorio X, Rivas $E$, Jara J. Prevalencia de tabaquismo en enfermeras de la IX Región, Chile. Rev Méd Chile 2003; $131(3): 269-74$.

17. Gonzalez L, Berger K. Consumo de tabaco en adolescentes: Factores de riesgo y factores protectores. Ciencia Enferm 2002; 8(2):27-35.

18. Hernández J, Guevara C, García M, Tascón J. Hábito de fumar en los estudiantes de primeros semestres de la Facultad de Salud: características y percepciones: Universidad del Valle, 2003. Colombia Med, 2006; 37(1):31-8.

19. Behn V, Cruz M, Huaiquián J, Naveas R, Sotomayor H. Motivación de no fumadores para continuar con esta conducta saludable. Ciencia Enferm 2003; 9(1):31-7.

20. Ortiz N, Costa MC. Meanings and contradictions of the drugs phenomenon: legal and illegal drugs in Chile. Rev Latino Am Enferm 2005; 13:903-11. 